\title{
PEMANFAATAN KEANEKARAGAMAN BAMBU SECARA HIDROLOGIS, EKONOMIS, SOSIAL DAN PERTAHANAN
}

\author{
Revi Mainaki'*, Rendra Zainal Maliki² \\ ${ }^{1}$ Program Studi Pendidikan Geografi, Fakultas Keguruan dan Ilmu Pendidikan, Universitas Siliwangi, Tasikmalaya, Indonesia \\ 2Program Studi Pendidikan Geografi, Fakultas Keguruan dan Ilmu Pendidikan, Universitas Tadulako, Palu, Indonesia \\ *Email Koresponden: revi.mainaki@unsil.ac.id \\ Diterima: 29-02-2020, Revisi: 12-05-2020, Disetujui 30-05-2020 \\ (C)2020 Program Studi Pendidikan Geografi, FISE, Universitas Hamzanwadi
}

\begin{abstract}
Abstrak Indonesia adalah salah satu negara dengan tingkat keanekaragaman sumberdaya hayati yang relatif tinggi. Salah satu sumberdaya hayati tersebut, adalah bambu. Keberadaan tanaman bambu di Asia termasuk Indonesia banyak dimanfaatkan ruas, buluh, pelepah, warna dan tingginya untuk berbagai keperluan. Penulisan artikel ini bertujuan untuk menjelaskan pemanfaatan keanekaragaman bambu secara hidrologis, ekonomis, sosial dan pertahanan di masyarakat, sebagai salah satu solusi alternatif pemanfaatan sumberdaya hayati di Indonesia. Jenis data yang digunakan adalah data literatur berupa hasil karya tulis ilmiah atau hasil penelitian yang relevan. Data yang telah terkumpul kemudian dianalisis dengan pendekatan deskriptif kualitatif. Hasil penelitian menunjukkan: 1) fungsi hidrologis bambu memberikan manfaat langsung sebagai tanaman konservasi mengurangi terjadinya erosi, penahan terjadinya longsor, penutup lahan yang baik untuk daerah tangkapan air, sedangkan secara tidak langsung sebagai penunjang kebutuhan air penduduk seperti untuk pipa, saluran dan tempat air; 2) fungsi ekonomi bambu membantu menunjang kebutuhan manusia, menambah pendapatan dan membuka kesempatan perekonomian baru seperti sebagai bahan konstruksi bangunan, anyaman, tulang beton, tali, alat sambung, atap, lantai dan jembatan; 3) Fungsi sosial dari bambu adalah memicu aktivitas sosial antar individu atau kelompok masyarakat, seperti pemanfaatan bambu untuk alat musik, obat tetes mata, alat pancing, tempat pembibitan, rakit dan pipa rokok; dan 4) Fungsi pertahanan bambu sendiri erat kaitannya dengan sejarah bangsa Indonesia terutama sebagai senjata dalam melawan penjajah, selain itu fungsi pertahanan bambu sendiri yakni sebagai medan pertahanan dan pagar hidup maupun buatan.
\end{abstract}

Kata kunci: bambu, fungsi hidrologis, fungsi ekonomi, fungsi sosial, fungsi pertahanan

\begin{abstract}
Indonesia is one of countries with a relatively bigh level of biodiversity. One of these biological resources, is bamboo. The existence of bamboo plants in Asia, including Indonesia, is widely used by segments, reeds, midribs, colors and height for various purposes. The writing of this article aims to explain the use of bamboo diversity in a hydrological, economic, social and defense manner in society, as one of the alternative solutions for the utilization of biological resources in Indonesia. The type of data used is literature data in the form of scientific papers or relevant research results. The data that has been collected is then analyzed using a qualitative descriptive approach. The results showed: 1) the bydrological function of bamboo provides direct benefits as a conservation plant reducing erosion, preventing landslides, good land cover for water catchments, while indirectly as a support for the population's water needs such as pipes, canals and water containers; 2) the economic function of bamboo helps to support buman needs, increase income and open up new economic opportunities such as building construction materials, plaits, concrete bones, ropes, connecting tools, roofs, floors and bridges; 3) The social function of bamboo is to trigger social activities between individuals or community groups, such as the use of bamboo for musical instruments, eye drops, fishing rods, nurseries, rafts and cigarette pipes; and 4) The function of bamboo defense itself is closely related to the history of the Indonesian people, especially as a weapon in the fight against invaders, in addition to the function of bamboo defense itself, namely as a defense field and live and artificial fences.
\end{abstract}

Keywords: bamboo, bydrological function, economic function, social function, defense function

\section{PENDAHULUAN}

Secara geografis, Indonesia terletak di antara Benua Asia dan Australia, Samudra Pasifik dan Hindia. Secara astronomis Indonesia juga termasuk wilayah yang beriklim tropis, dipengaruhi oleh angin 
muson sehingga menyebabkannya memiliki dua musim (kemarau dan hujan). Kondisi geografis dan astronomis tersebut menyebabkan Indonesia memiliki keanekaragaman hayati terbesar kedua di dunia setelah Brazil. Keanekaragaman tersebut salah satunya meliputi sumberdaya hutan yang menghasilkan kayu maupun non kayu sebagai komoditas yang khas. Sumberdaya hutan sangat penting bagi suatu negara, salah satunya untuk meningkatkan kondisi ekonomi bangsa (Kigomo, 2007 dalam Mainaki, 2015). Keberadaan sumberdaya hutan tersebut terutama di negara dengan iklim tropis, karena akan ditemukan jenis tanaman yang sangat beragam sesuai dengan beberapa hasil penelitian yang pernah dilakukan (Ervianti et al., 2019). Oleh sebab itu sumberdaya hutan harus terus dilestarikan agar dapat memberikan berbagai manfaat baik secara ekologis, sosial maupun ekonomi (Hadi, 2018).

Salah satu sumberdaya hutan yang dapat dimanfaatkan dan cukup familiar di tengah-tengah masyarakat adalah jenis tanaman bambu. Tanaman bambu merupakan salah satu bahan yang dapat dimanfaatkan untuk berbagai tujuan, karena sejak jaman dahulu manusia telah menggunakan bambu sebagai bahan bangunan, mebel, alat rumah tangga dan barang kerajinan. Bambu yang termasuk tanaman cepat tumbuh dan mempunyai daur yang relatif pendek merupakan salah satu sumberdaya alam yang cukup menjanjikan sebagai bahan substitusi kayu (Sulastiningsih \& Santoso, 2012). Populasi bambu dunia terdiri atas 75 marga dan 1250 - 1350 jenis. Di Indonesia diduga terdapat 157 jenis bambu. Jumlah ini merupakan lebih dari 10\% jenis bambu dunia. 50\% bambu Indonesia merupakan jenis endemik dan lebih dari $50 \%$ merupakan jenis bambu yang telah dimanfaatkan oleh penduduk dan sangat berpotensi untuk dikembangkan (Uchimura, 1977; Widjaya, 2004, dalam Yani, 2012).

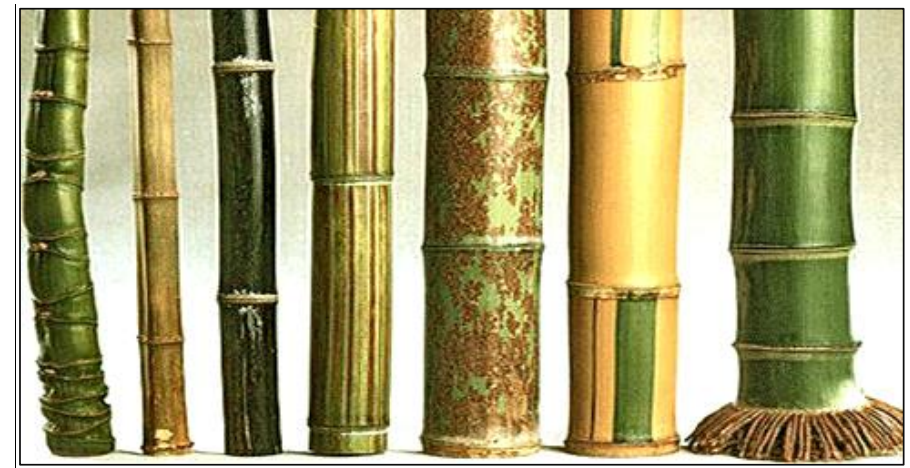

Gambar 1. Keanekaragaman jenis bambu (Sumber: Phil, 2007 dalam Mainaki, 2015)

Di zaman industri, khususnya pada abad 21 ini kita dihadapkan dengan jenis bahan bangunan yang tidak dapat dilepaskan dari material besi, plastik dan batu jenis tertentu. Namun demikian, bambu sebenarnya memiliki keuntungan lain dibandingkan dengan material tersebut. Keutungan lain yang dimaksud terutama disebabkan karena bambu memiliki karakter yang fleksibel (mudah dibentuk), berpotensi untuk bentukbentuk lengkung (bentuk yang cukup sulit dicapai dengan material konstruksi lainnya). Potensi ini yang digunakan oleh para perancang untuk memanfaatkan bambu sebagai material struktural bangunan untuk melahirkan bangunan organik dengan bentuk atap bergelombang (Maurina, 2014). Penelitian tentang bambu sebagai bahan material bukanlah hal yang baru, karena telah dilakukan sejak zaman Dinasti Jin di China terutama pada tahun 265-420 Masehi. (Wang, 2000 dalam Mainaki, 2015).

Tanaman bambu di Indonesia cukup banyak dapat ditemui terutama di wilayah perdesaan maupun kawasan hutan (Sastrapraja, et al., 1977; Sulastiningsih \& Santoso, 2012; Ervianti et al., 2019). Terutama meliputi daerah pedesaan di Pulau Jawa, Sumatera, Papua, Nusa Tenggara, Bali, Kalimantan dan Maluku. Persebaran habitat tanaman bambu di Indonesia yang hampir tersebar merata menjadikannya sebagai prospek yang sangat menjanjikan. Terutama jika melihat jumlah penduduk di Indonesia yang mencapai sekitar 250 juta jiwa. Bambu juga merupakan alternatif pemilihan bahan material bangunan yang murah dan mudah, serta banyak ditemui terutama di daerah yang termasuk dalam iklim tropis. Hampir Semua jenis tanah dapat ditanami bambu kecuali tanah di daerah pantai. Pada tanah ini kalaupun terdapat bambu, pertumbuhannya lambat dan batangnya kecil. Tanaman 
bambu dapat dijumpai mulai dari dataran rendah sampai dataran tinggi, dari pegunungan berbukit dengan lereng curam sampai landai (Sastrapraja, et al., 1977 dalam Sulastiningsih \& Santoso, 2012).

Pertumbuhan bambu relatif lebih cepat jika dibandingkan dengan tanaman kayu lain. Kareakteristik akar bambu memiliki kemampuan mengikat struktur tanah yang baik, sehingga dapat mencegah terjadinya erosi tanah yang menyebabkan longsoran. Bambu merupakan tanaman yang baik untuk konservasi tanah karena memiliki pertumbuhan relatif lebih cepat dan dapat menahan permukaan tanah dari aliran atau percikan air. Kemampuan bambu yang dapat dijadikan tanaman konservasi tanah sesuai dengan syarat tanaman konservasi tanah, khususnya dalam menanggulangi masalah erosi tanah seperti: 1) mudah diperbanyak; 2) tidak mengsyaratkan tanah yang terlalu subur; 3) memiliki sistem perakaran yang dapat mengikat struktur tanah; 4) tumbuh cepat dengan menghasilkan daun atau pelepah; 5) tahan terhadap hama, penyakit dan kekeringan; 6) mudah dibasmi jika lahan akan digunakan; 7) tidak memiliki sifat yang membuat tidak nyaman seperti berduri dan sulur yang melilit; 8) memiliki nilai manfaat (Arsyad, 2012).

Tentunya pertumbuhan tanaman bambu sangat dipengaruhi oleh kondisi lingkungannya, namun dalam tumbuhnya bambu tidak memerlukan lingkungan yang rumit. Pertumbuhan bambu tidak terlepas dari pengaruh kondisi lingkungan tempat tumbuh, terutama: 1) Tanah dengan $\mathrm{pH} 5,6-6,5 ; 2$ ) Ketinggian tempat, $0-2000 \mathrm{~m} \mathrm{dpl}$; 3) Suhu $8,8-36^{\circ} \mathrm{C}$; 4) curah hujan tahunan minimal $1.020 \mathrm{~mm}$, dan 5) kelembaban $80 \%$ Mainaki (2015). Tanpa disadari, bambu juga merupakan tanaman yang dapat tumbuh di tanah-tanah marjinal sehingga tanaman ini dapat mendorong masyarakat untuk membudidayakannya dan menjaga fungsi konservasi tanah sebagai daerah resapan air.

Bambu selain memiliki fungsi konservasi tanah dan air, bambu juga memiliki fungsi ekonomi karena menjadi salah satu komoditas perdagangan internasional INBAR (International Network for Bamboo and Rattan) tahun 2005 (Mainaki, 2015). Perdagangan bambu internasional bernilai sekitar USD 5,5 miliar/tahun. Sedangkan pada tahun 2007 telah meningkat menjadi USD 7 miliar/tahun. Pertumbuhan pasar global diprediksikan mencapai USD 15-17 miliar/tahun pada tahun 2017. Bambu sebagai bahan konstruksi rumah maupun barang kebutuhan lainnya tidak hanya dibutuhkan di Indonesia. Beberapa Negara lain terutama di asia juga menjadikan bambu sebagai bahan konstruksi, baik untuk pembangunan rumah maupun sebagai bahan pembuatan barang kebutuhan lainnya (Tabel 1). Hal ini tentu saja disebabkan karena adanya kemudahan dalam memperoleh bahan bangunan atau bahan kebutuhan lainnya yang terbuat dari bambu.

Tabel 1. Konsumsi bambu sebagai fungsi ekonomis di beberapa negara Asia

\begin{tabular}{|c|c|c|c|c|c|c|}
\hline \multirow{2}{*}{ NEGARA } & \multicolumn{2}{|c|}{ KONSTRUKSI } & \multirow{2}{*}{$\begin{array}{l}\text { PENGGUNAAN } \\
\text { DI DESA }\end{array}$} & \multirow{2}{*}{$\begin{array}{l}\text { PEM- } \\
\text { BUNGKUS }\end{array}$} & \multirow{2}{*}{$\begin{array}{l}\text { PABRIK } \\
\text { PULP }\end{array}$} & \multirow{2}{*}{$\begin{array}{l}\text { LAIN- } \\
\text { LAIN }\end{array}$} \\
\hline & RUMAH & LAIN & & & & \\
\hline Bangladesh & 50 & 10 & 20 & 5 & 10 & 5 \\
\hline Burme & 53 & 32 & 32 & 5 & - & 1 \\
\hline India & 16 & 16 & 30 & 7 & 17 & 14 \\
\hline Jepang & 24 & 7 & 18 & 7 & 4 & 41 \\
\hline Philipina & 80 & - & 15 & 2 & - & 3 \\
\hline Tha1land & 33 & 20 & 16 & $=$ & 8 & 33 \\
\hline
\end{tabular}

Sumber: Sitorus, 1997 dalam Mainaki, 2015.

Fungsi hidrologis dan ekonomis bambu telah diuraikan sebelumnya, sehingga kita mendapatkan sedikit gambaran mengenai dua fungsi bambu tersebut. Namun demikian, tidak hanya itu, bambu juga memiliki fungsi lainnya, yaitu fungsi sosial dan fungsi pertahanan. Hal inilah yang akan coba kita gali lebih mendalam melalui penelitian ini. Penelitian-penelitian mengenai pemanfaatan bambu masih fokus pada fungsi tertentu saja atau hanya fokus pada satu aspek (parsial). Iqbal et al., (2014) misalnya mengkaji nilai ekonomi total sumberdaya bambu (Bambuseae Sp.) Di Kecamatan Sajira, Kabupaten Lebak, Banten. Dalam fungsi hidrologisnya bambu juga dijadikan sebagai tanaman untuk rehabilitasi lahan dan konservasi tanah di sekitar mata air pada lahan marginal di Bali Timur (Raka et al., 2011). Fungsi sosial bambu misalnya dapat dilihat pada pembuatan alat musik sebagai sarana ekspresi sosial- 
estetis. Penelitian dari Oktawirani et al., (2016) misalnya mengkaji pembuatan alat musik Angklung dengan bahan baku bambu di Saung Angklung Udjo. Sementara fungsi pertahanan ditunjukkan oleh penelitian yang dilakukan Sari (2011) yang mengkaji inventarisasi dan pemanfaatan bambu di desa sekitar tahura Kabupaten Karo. Ia menyatakan bahwa fungsi pertahanan ini dapat dikatakan sangat tradisional dan bersifat historis, yang dialami masyarakat pada zaman penjajahan. Dengan masih parsialnya penelitian mengenai pemanfaatan bambu ini maka peneliti tergerak dan bertujuan untuk melakukan kajian mendalam dan komprehensif mengenai keempat fungsi bambu tersebut (Hidrologis, Ekonomis, Sosial dan Pertahanan) di tengah-tengah masyarakat.

\section{METODE PENELITIAN}

Penelitian ini dimaksudkan untuk mendeskripsikan keanekaragaman bambu, khususnya di Indonesia terutama dari beberapa aspek seperti: 1) aspek hidrologis yang berkenaan dengan air yang ada dipermukaan bumi; 2) aspek ekonomis berkenaan dengan kebutuhan hidup manusia; 3) aspek sosial berkenaan dengan hubungan sosial antar individu dengan individu, individu dengan kelompok atau kelompok dengan kelompok; dan 4) aspek pertahanan yang berkaitan dengan kekuatan keamanan dan ketertiban bagi masyarakat. Berbagai aspek tersebut dikaji dengan pendekatan studi literatur yang dilakukan selama bulan November dan Desember tahun 2019. Hasil kajian ini dibahas menggunakan metode deskriptif. Pemaparan mengenai pokok permasalahan yang dikemas dalam berbagai tinjauan terhadap fakta-fakta yang terjadi di masyarakat berdasarkan data-data konkret dan aktual. Data-data tersebut diperoleh dari berbagai sumber dan berbagai cara, di antaranya penulis melakukan studi pustaka dari beberapa buku maupun artikel yang menunjang terhadap topik yang dibahas dan melakukan pengumpulan referensi-referensi lain dari beberapa website yang relevan. Hal ini dilakukan guna memperoleh data yang faktual, terkini, dan informatif (Prabowo \& Heryanto, 2013; Linarwati et al., 2016; Ihwanul \& Perdhana, 2017; Christina, 2018).

\section{TEMUAN DAN PEMBAHASAN}

\section{Fungsi Hidrologis Bambu}

Budiyanto et al., (2020) menyatakan bahwa fungsi hidrologis bambu terbagi menjadi dua jenis, yakni fungsi langsung dan fungsi tidak langsung:

1) Fungsi Langsung

Fungsi bambu secara langsung diantaranya sebagai penutup lahan untuk mengurangi erosi dan sekaligus sebagai daerah tangkapan air hujan. Pada hakekatnya semua jenis bambu memiliki fungsi ini, bambu memiliki akar yang cukup kuat dan tanaman dengan pelepah yang cukup lebar jika ditanam di daerah perbukitan atau disamping lereng akan membantu mengikat struktur tanah dan menghindari bahaya longsor. Vegetasi yang cocok untuk menjadi tanaman pengurangan dampak erosi sebagaimana dikemukakan Arsyad (2012) adalah :1) mudah diperbanyak; 2) tidak mensyaratkan tanah yang terlalu subur; 3) memiliki sistem perakaran yang dapat mengikat struktur tanah; 4) tumbuh cepat dengan menghasilkan daun atau pelepah; 5) tahan terhadap hama, penyakit dan kekeringan; 6) mudah dibasmi jika lahan akan digunakan; 7) tidak memiliki sifat yang membuat tidak nyaman seperti berduri dan sulur yang melilit; 8) memiliki nilai manfaat. Tanaman bambu termasuk memiliki bebetapa karakteristik sebagaimana syarat tersebut, sehingga cocok untuk dijadikan tanaman konservasi terutama secara hidrologis.

2) Fungsi Tidak Langsung

Merupakan fungsi bambu secara tidak langsung terutama untuk kepentingan manusia dalam memenuhi kebutuhan airnya. Pada fungsi ini masyarakat memanfaatkan bambu diantaranya sebagai pipa, saluran dan tempat air. Jenis bambu yang biasanya dimanfaatkan dengan fungsi hidrologis secara tidak langsung diantaranya adalah ater, betung, eul-eul, betung, lengka, sembilang dan talang.

\section{Fungsi Ekonomis Bambu}

Bambu seperti yang telah dipaparkan sebelumnya memiliki fungsi ekonomis yakni fungsi untuk membantu menunjang kebutuhan ekonomi manusia, menambah pendapatan dan menghidupkan 
perekonomian masyarakat, berikut merupakan penjelasan lebih spesifik dari fungsi ekonomis bambu (Chaowana, 2013 dan Anoyke et al., 2016):

1) Bahan Konstruksi Bangunan

Diantara sekian banyak jenis bambu hanya beberapa dari banyaknya kenis bambu yang digunakan sebagai bahan untuk konstruksi bangunan. Bambu yang dapat digunakan sebagai bahan untuk konstruksi bangunan terutama yang memiliki buluh yang kuat dan lentur, jenis tersebut antara lain: a) bambu tali/apus; b) Bambu hitam/wulung; c) Bambu petung; dan d) bambu duri/ori.

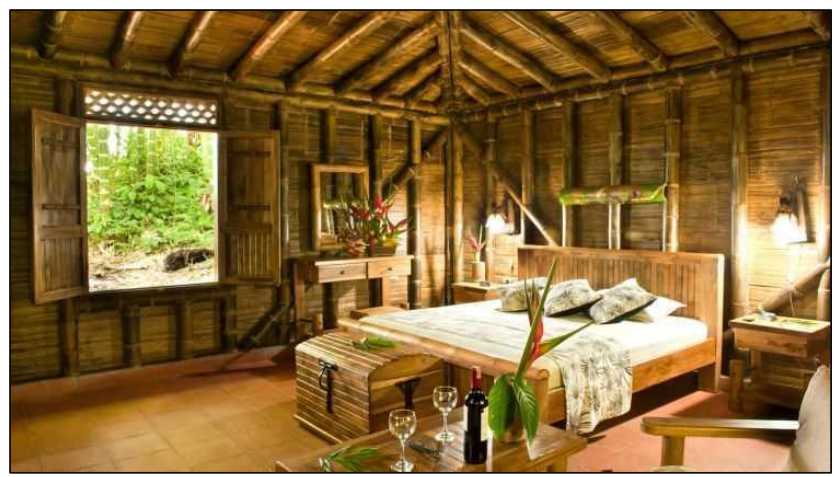

Gambar 2. Bambu sebagai bahan konstruksi bangunan (Sumber: arsitag.com, 2020)

2) Bahan Anyaman

Bambu yang memiliki serat pada batang menyebabkannya cocok untuk dijadikan sebagai bahan anyaman, anyaman tersebut kemudian dapat menjadi berbagai alat penunjang untuk memenuhi kebutuhan hidup manusia. Anyaman adalah susunan atau lungsin bambu yang sudah dipotong dengan tipis, dengan pola tertentu.

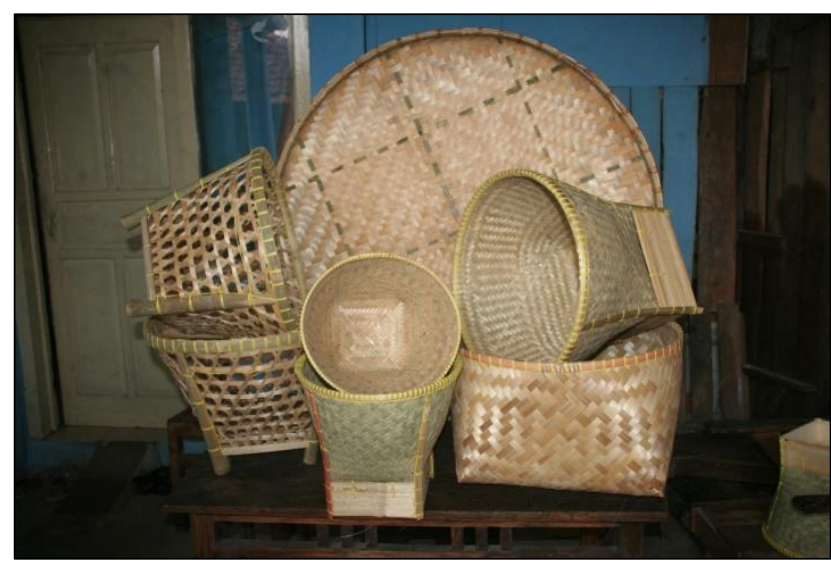

Gambar 3. Bahan anyaman dari bambu (Sumber: goodnewsfromindonesia.id, 2020)

3) Beton Tulang Bambu

Bambu dapat dijadikan menjadi bahan subtitusi untuk tulang beton jenis besi, dengan kekuatan yang relatif mirip dengan besi. Bambu bisa dijadikan alternatif dalam mengganti tulang beton bangunan yang relatif tidak memerlukan konstruksi besi yang disyaratkan (Frick, 1997 dalam Mainaki, 2015). 


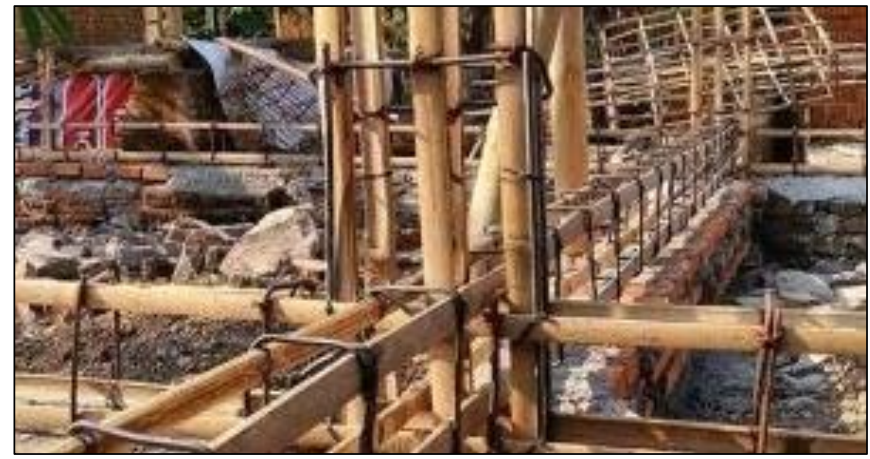

Gambar 4. Tulang beton yang menggunakan bahan bambu (Sumber: jharwinata.blogspot.com, 2020)

4) Tali Bambu

Bambu dengan serat yang cukup kuat, terutama pada jenis bambu tertentu menyebabkan tanaman tersebut dapat dijadikan sebagai bahan subtitusi plastik untuk menjadi tali, dengan menjadikan bambu tali maka kita turut menjaga lingkungan dari limbah plastik yang kurang toleran bagi lingkungan.

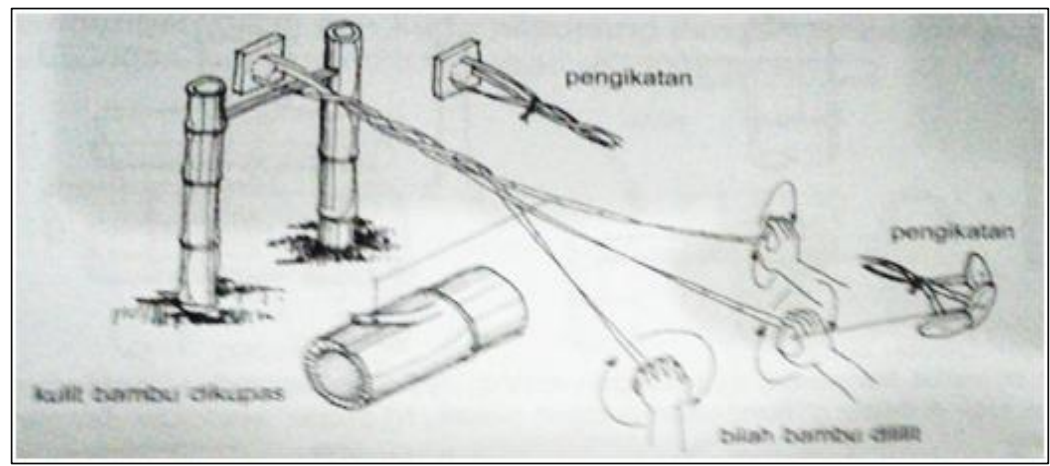

Gambar 5. Pembuatan tali dari bahan bambu (Sumber: Frick, 2004 dalam Mainaki, 2015)

5) Alat Sambung Bambu

Alat dimana bambu dapat dipakai sebagai sambungan dari sebuah saluran yang dapat menjadi bahan subtitusi dari kayu dan plastik untuk saluran jenis tertentu (lihat gambar 6).

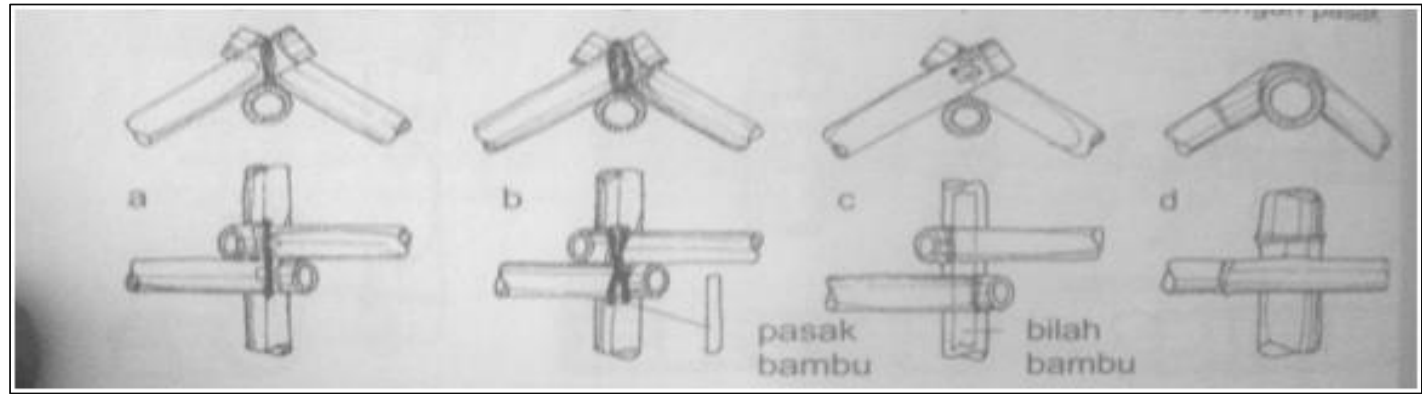

Gambar 6. Sambungan saluran alternatif dari bambu (Sumber: Frick, 2004 dalam Mainaki, 2015)

6) Atap Bangunan

Bambu dapat dijadikan menjadi bahan untuk menutup rumah atau menjadi bahan subtitusi untuk genteng, dimana bambu memiliki nilai ekonomis sebagai pengganti genteng (lihat gambar 7). 

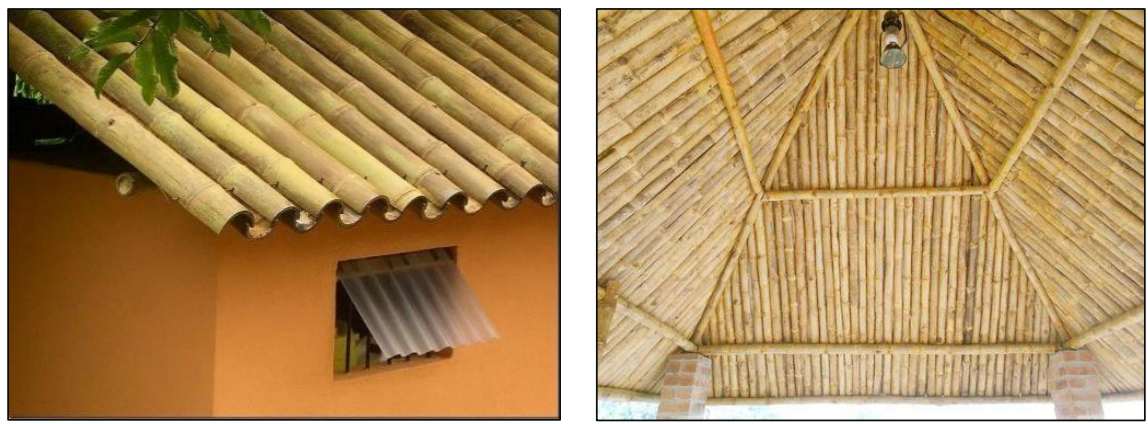

Gambar 7. Bahan atap dari bambu

(Sumber: goodshomedesign.com \& indiamart.com, 2020)

7) Lantai Bambu

Bambu dapat menjadi bahan subtitusi keramiik atau bahan yang biasanya dijadikan lantai, karena serat yang kuat dan permukaan kulit yang tidak terlalu kasar, bambu dapat disusun dengan baik sehingga menjadi pijakan nyaman dan terjangkau.

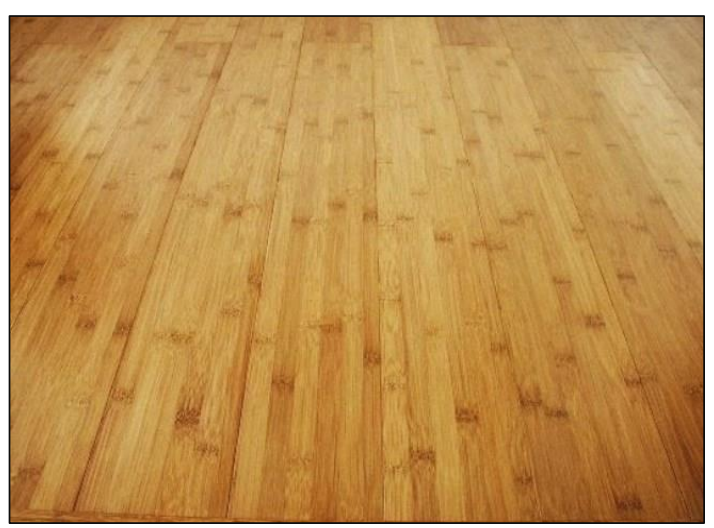

Gambar 8. Bahan lantai dari bambu

(Sumber: rumahminimalis2016.com, 2020)

8) Konstruksi Jembatan.

Bambu merupakan bahan yang banyak dan mudah ditemui terutama di daerah perdesaan, untuk membuat sebuah jembatan diperlukan bahan bangunan yang cukup kuat diantaranya adalah konstruksi beton, namun konstruksi tersebut nyatanya dapat digantikan oleh bambu karena pada dasarnya bambu memiliki serat yang cukup kuat jika disatukan dan dapat menjadi bahan alternatif konstruksi jembatan, untuk membawa material konstruksi jembatan yang cukup rumit ke daerah perdesaan akan memakan waktu dan biaya yang tidak sedikit, maka dari itu bambu dapat menjadi bahan alternatif untuk membuat konstruksi jembatan.

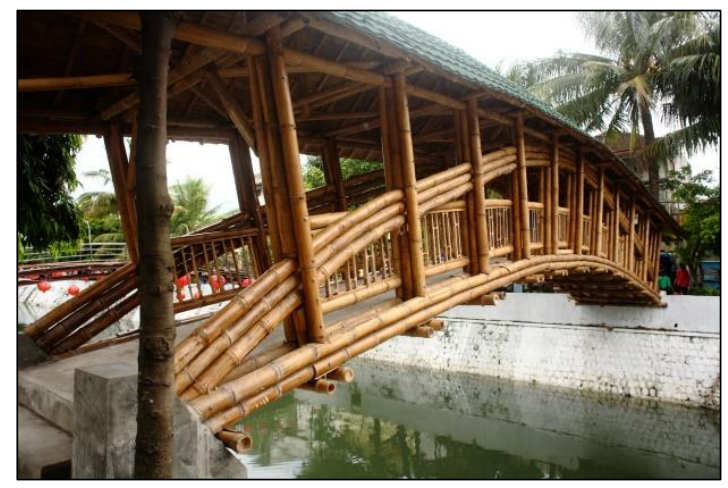

Gambar 9. Konstruksi jembatan dari bambu (Sumber: ikons.id, 2020) 


\section{Fungsi Sosial Bambu}

Bambu memiliki fungsi sosial, fungsi ini adalah fungsi yang memicu manusia dalam melakukan aktivitas sosialnya. Masyarakat dapat memperoleh manfaat sosial dari keberadaan bambu, karena bambu memiliki fungsi tersebut. Bambu dikatakan memiliki fungsi sosial ketika berkenaan dengan hubungan manusia (Sujarwo, 2018). Hubungan ini meliputi hubungan interaksi masyarat antara individu dan kelompok, antara individu dan individu serta kelompok dan kelompok. Maka kita dapat menggolongkan beberapa fungsi sosial bambu diantaranya sebagai alat musik, obat tetes mata, tempat pembibitan, alat pancing, rakit dan pipa rokok (Sitorus, 1977 dalam Mainaki, 2015).

1) Alat Musik

Bambu dengan karakteristik yang khas beberapa jenis dapat dijadikan sebagai alat musik, beberapa daerah di Indonesia memiliki alat musik yang khas terbuat dari bambu yang dapat memicu aktivitas sosialnya misalnya di Jawa Barat ada angklung (Gambar 10.A), kemudian di beberapa provinsi lain ada suling dan juga ada kesenian khas Jawa Barat yakni calung. Jenis bambu yang dapat dijadikan alat musik diantaranya adalah ater, hitam, tali, toi dan tamiang.

2) Obat Tetes Mata

Bambu dapat menyimpan air di dalam rongganya dan air pada pucuk bambu muda dapat dimanfaatkan sebagai obat tetes mata, jenis bambu yang dapat dimanfaatkan sebagai obat tetes mata adalah jenis cangkoreh. Dipercaya air yang tersimpan dalam jenis bambu ini yang masih muda dapat membantu meringankan iritasi mata.

3) Tempat Pembibitan

Tempat pembibitan tanaman merupakan fungsi sosial bambu yang dapat diperoleh atau dibuat langsung oleh masyarakat dengan cukup mudah (Gambar 10.B).

4) Alat Pancing

Bambu yang tidak terlalu tua dan tidak terlalu muda memiliki serat yang cukup elastis mirip dengan jenis plastik fiber, sehingga cukup baik digunakan sebagai alat pancing. Bagi masyarakat khususnya di perdesaan, alat pancing bambu dapat digunakan sebagai sarana rekreasi dan sarana sosial dalam meghabiskan waktu dengan memancing bersama. Beberapa jenis bambu yang dapat dijadikan alat pancing adalah jenis pagar, perling dan tamiang (Gambar 10.C).

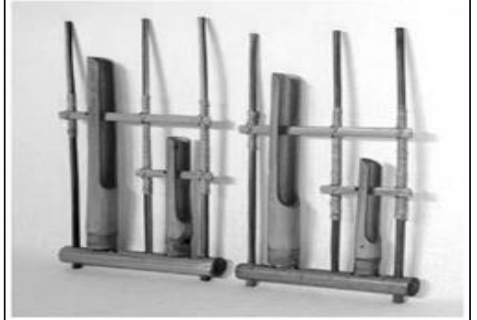

A

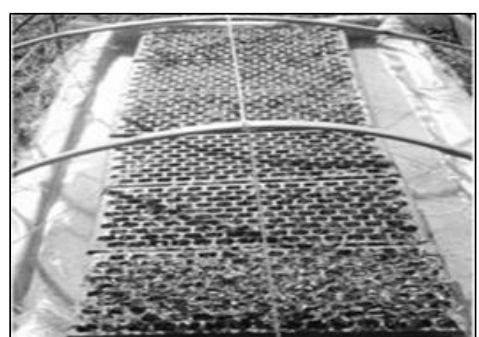

B

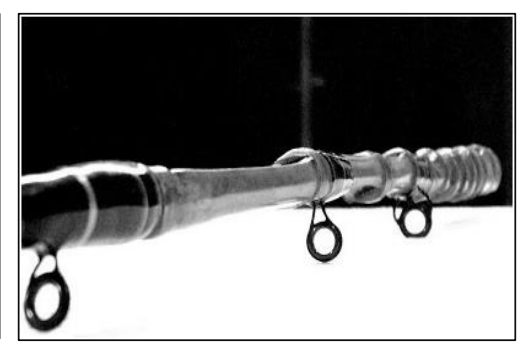

C

Gambar 10. Peralatan dari bambu: alat musik angklung (A), tempat pembibitan (B), dan alat pancing (C) (Sumber: Mainaki, 2015)

\section{5) Rakit/alat transportasi}

Bambu yang memiliki rongga di bagian batangnya dapat mengapung ketika masuk ke dalam air, sehingga dapat digunakan untuk bahan pembuatan rakit. Rakit ini dimanfaatkan oleh masyarakat sebagai alat transportasi, terutama digunakan pada sungai maupun bentang alam perairan lainnya. Jenis bambu yang baik digunakan sebagai rakit karena kekuatan dan karakteristiknya adalah jenis bambu talang (Gambar 11.A).

6) Pipa Rokok

Bambu dengan rongga udara yang tidak terlalu besar dan usia tidak terlalu tua dengan kerapatan pori yang tidak terlalu renggang dapat digunakan sebagai pipa rokok, sehingga rokok tidak bersentuhan langsung dengan mulut dan bara api dari rokok lebih jauh dari mulut. Jenis bambu yang baik untuk dijadikan sebagai pipa rokok diantaranya adalah jenis bambu uncue (Gambar 11.B). 


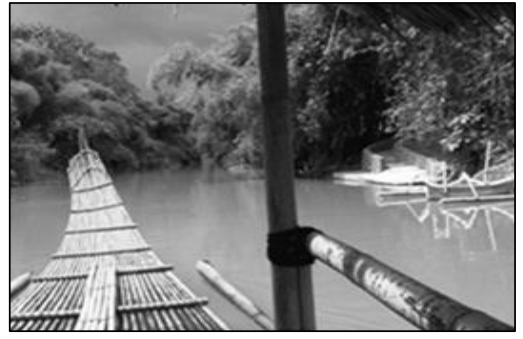

A

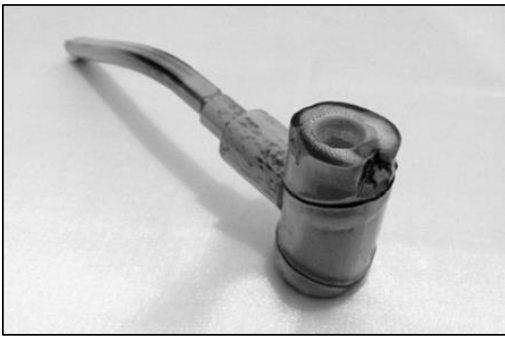

B

Gambar 11. Peralatan dari bambu: rakit sebagai alat transportasi perairan (A), pipa rokok (B)

(Sumber: Mainaki, 2015)

\section{Fungsi Pertahanan Bambu}

Fungsi pertahanan bambu erat kaitannya dengan sejarah perjuangan dan perlawanan bangsa Indonesia melawan para penjajah. Hal ini karena bambu memiliki batang yang cukup kuat dan memungkinkan untuk dijadikan sebagai sarana pertahanan seperti senjata, medan pertahanan maupun pagar hidup (Darmadi, 2018; Awalludin et al., 2017).

1) Senjata Tradisional

Indonesia merdeka salah satunya berjuang melawan penjajah dengan menggunakan bambu runcing sebagai senjata (Gambar 12.A). Bambu juga di beberapa daerah di Indonesia masih dipertahankan sebagai senjata tradisionalnya, seperti untuk berburu dan hanya sebagai simbol pelengkap upacara adat. Daerah papua misalnya yang masih menggunakan jenis senjata tradisional pisau belati dari bambu. Busur dan anak panah juga dapat dibuat dari bambu. Jenis bambu yang dapat dimanfaatkan sebagai senjata tradisional diantaranya adalah ater, eul-eul, gombong dan toi.

2) Medan Pertahanan

Bambu yang memiliki rumpun cuput rapat sehingga dapat membuat jenis hutan bambu akan menjadi vegetasi penutup lahan yang efektif ketika berperang sebagai arena persembunyian dan membuat strategi pertahanan di hutan bambu (Gambar 12.B).

3) Pagar Hidup dan pagar buatan

Bambu yang selain dapat tumbuh dengan mudah juga sangat resisten atau kuat menahan berbagai jenis hama, sehingga cocok untuk dijadikan sebagai pagar hidup di pekarangan rumah. Bambu juga dapat dijadikan pagar buatan dengan jenis konstruksi tertentu. Jenis bambu yang cocok dijadikan baik pagar hidup maupun pagar buatan adalah bambu jenis ater, eul-eul, gombong, lengka, pagar, tali dan uncue (Gambar 12.C).

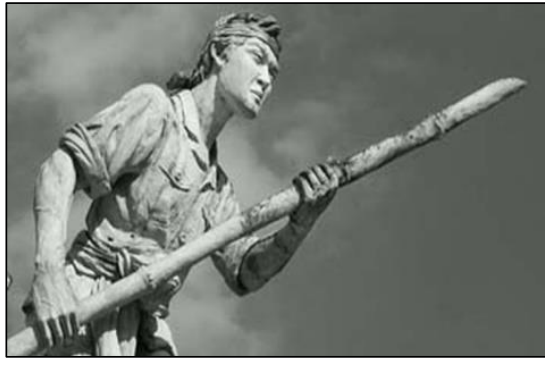

A

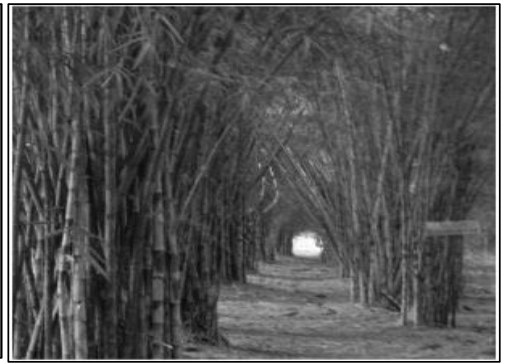

B

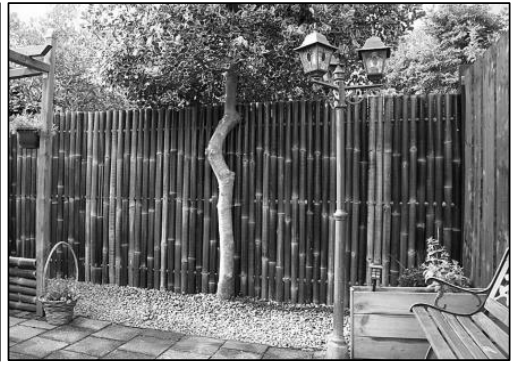

C

Gambar 12. Manfaat bambu sebagai fungsi pertahanan: senjata bambu runcing (A), Hutan bambu sebagai medan pertahanan/persembunyian perang $(\mathrm{B})$, pagar sebagai pelindung $(\mathrm{C})$.

(Sumber: google.com dan kompasiana.com, 2015)

\section{SIMPULAN}

Bambu merupakan jenis tanaman yang mudah tumbuh dan tidak terlalu sulit untuk berkembang biak khususnya di daerah beriklim. Sejak dulu bambu banyak dimanfaatkan sebagai tanaman yang membantu memenuhi kebutuhan hidup manusia. Secara hidrologis bambu memberikan a) manfaat langsung sebagai tanaman konservasi terutama untuk mengurangi terjadinya erosi, penahan terjadinya longsor, 
penutup lahan yang baik untuk daerah tangkapan air; b) secara tidak langsung untuk penunjang kebutuhan air penduduk seperti untuk pipa, saluran dan tempat air. Secara ekonomi bambu membantu menunjang kebutuhan manusia, menambah pendapatan dan membuka kesempatan perekonomian baru seperti sebagai bahan konstruksi bangunan, anyaman, tulang beton, tali, alat sambung, atap, lantai dan jembatan. Fungsi sosial dari bambu adalah memicu aktivitas sosial antar individu atau kelompok masyarakat, seperti pemanfaatan bambu untuk alat musik, obat tetes mata, alat pancing, tempat pembibitan, rakit dan pipa rokok. Fungsi pertahanan bambu sendiri erat kaitannya dengan sejarah bangsa Indonesia sendiri sebagai senjata dalam melawan penjajah, selain itu fungsi pertahanan bambu sendiri yakni sebagai medan pertahanan dan pagar hidup maupun buatan. Tanaman bambu memiliki manfaat yang cukup banyak bagi kehidupan manusia. Alangkah lebih baik jika tanaman ini diteliti lebih mendalam dan direkomendasikan oleh pihak berwenang untuk dapat dibudidayakan masyarakat sebagai tanaman konservasi hidrologis, tanaman subtitusi berbagai bahan konstruksi yang relatif lebih mahal, bahan kerajinan bernilai ekonomis, sebagai sarana sosial serta pertahanan yang efektif dan ramah lingkungan.

\section{DAFTAR PUSTAKA}

Anoyke, R., Bakar, S. E., Ratnasingam, J., \& Awang, K. (2016). Bamboo properties and suitability as a replacement for wood. Jurnal Pertanika, 2(1), 68-80.

Arsyad, S. 2012. Konservasi tanah dan air. Bogor: IPB Press. Edisi Kedua.

Awalluddin, D., Ariffin, M., Azreen, M., Osman, M. H., Hissi, M. W., Ismail, M. A., Lee, H. S., \& Lim, A. A. (2017). Mechanical properties of different bamboo species. Jurnal Matec Web Conferences, 138, $1-10$.

Budiyanto, H., Setiawan, A. B., Haris, M., Iqbal, M., \& Sonalitha, E. (2020). The bamboo greenhouse technology for hydroganic plants with independent photovoltaic energy in the food safety program. Jurnal Local Wisdom, 12(1), 10-18.

Chaowana, P. (2013). Bamboo: An alternative raw material for wood and wood-based composites. Journal of Materials Science Research, 2(2), 90-102.

Christina, A. D. (2018). Peran media sosial (Facebook, Instagram, Youtube) dalam menarik wisatawan mengunjungi objek wisata Tetempangan Hill Kabupaten Minahasa Provinsi Sulawesi Utara. Jurnal Undhira Bali, 13(1), 75-80.

Darmadi, H. (2018). Sumpit (blowgun) as traditional weapons with Dayak high protection. Journal of Education, Teaching and Learning, 3(1), 113-120.

Ervianti, D., Widjaja, E. A., \& Sedayu, A. (2019). Bamboo diversity of Sulawesi, Indonesia. Jurnal Biodiversitas, 20(1), 91-109.

Hadi, H. (2018). Analisis dampak pengelolaan Hutan Kemasyarakatan (HKm) di Desa Sapit Kecamatan Suela Kabupaten Lombok Timur. Geodika: Jurnal Kajian Ilmu dan Pendidikan Geografi, 2(1), 9-21.

Ihwanul, M. M., \& Perdhana, M. S. (2017). Glass ceiling: sebuah studi literatur. Jurnal Bisnis Strategy, 26(1), 28-38.

Iqbal, M., Putri, E. I. K., \& Bahruni, B. (2014). Nilai ekonomi total sumberdaya bambu (bambuseae sp.) di Kecamatan Sajira, Kabupaten Lebak, Banten. Jurnal Penelitian Sosial dan Ekonomi Kehutanan, 11(2), 91-105.

Kompasiana. (2012). Surabaya dan butan bambunya. Diakses pada 15 November 2015, dari https://bit.ly/2WCG7IW.

Linarwati, M., Fathoni, A., \& Minarsih, M. (2016). Studi deskriptif pelatihan dan pengembangan sumberdaya manusia serta penggunaan metode behavioral event interview dalam merekrut karyawan baru di bank Mega cabang Kudus. Jurnal of Management, 2(2), 1-8. 
Mainaki, R. (2015). Keanekaragaman Bambu dan Fungsinya di Indonesia. Makalah, tidak dipublikasikan. Bandung: Sekolah Pascasarajana Universitas Pendidikan Indonesia.

Maurina, A. (2014). Penggunaan bambu pada struktur rangka dan struktur permukaan aktif pada bangunan organik dengan bentuk atap bergelombang. Prosiding Seminar Nasional Bamboo Biennale 2014 "Reinkarnasi Bambu dalam Kekinian".

Oktawirani, P., Muntasib, E. K. S., \& Zuhud, E. A. (2016). Perencanaan interpretasi berbasis konservasi bambu sebagai bahan baku Angklung di Saung Angklung Udjo. Tesis, tidak dipublikasikan. Bogor: Institut Pertanian Bogor.

Prabowo, A., \& Heryanto. (2013). Analisis Pemanfaatan buku elektronik ( e-book ) oleh pemustaka di perpustakaan SMA Negeri 1 Semarang. Jurnal Ilmu Perpustakaan, 2(2), 1-9.

Raka, I. D. N., Wiswasta, I. A., \& Budiasa, I. M. (2011). Pelestarian tanaman bambu sebagai upaya rehabilitasi lahan dan konservasi tanah di daerah sekitar mata air pada lahan marginal di Bali Timur. Jurnal Agrimeta, 1(1).

Sari, N. (2011). Inventarisasi dan pemanfaatan bambu di desa sekitar Tabura kabupaten Karo. Skripsi, tidak dipublikasikan. Medan: Universitas Sumatera Utara.

Sujarwo, W. (2018). Bamboo resources, cultural values, and ex-situ conservation in Bali, Indonesia. Jurnal Reinwardtia, 17(1), 67-75.

Sulastiningsih, I. M., \& Santoso, A. (2012). Pengaruh jenis bambu, waktu kempa dan perlakuan pendahuluan bilah bambu terhadap sifat papan bambu Lamina. Jurnal Penelitian Hasil Hutan, 30(3), 199-207.

Yani, A. P. (2012). Keanekaragaman dan populasi bambu di Desa Talang Pauh Bengkulu Tengah. Exacta, 10(1), 61-70. 